\title{
Pulmonary Talcosis With Intravenous Drug Abuse
}

\author{
Mohammad F Siddiqui MD MPH, Sabah Saleem MD, and Sridhar Badireddi MD
}

\section{Introduction}

Talc has been known to cause lung disease, via inhalation or intravenously. A good history along with radiological correlation will often reveal the diagnosis. However, most intravenous drug abusers are reluctant to give a history of exposure, and most diagnoses are made after lung biopsy. We present a case of acute respiratory failure that posed a diagnostic challenge and was diagnosed only after a biopsy.

\section{Case Summary}

A 34-year-old white male presented with dyspnea, fatigue, and dry cough. A day prior he had reported a syncopal episode, and did not recollect the preceding events. On regaining consciousness he thought he had had a seizure, given a prior episode from benzodiazepine withdrawal a year earlier. He presented to his primary care physician, where he was noted to be severely hypoxemic $\left(\mathrm{S}_{\mathrm{pO}_{2}}\right.$ 60-65\%), and was transferred to the emergency department. He denied any chest pain, palpitations, fever, chills, or night sweats.

His medical history was notable for depression, for which he was on trazodone. He also took over the counter analgesics as needed for chronic back pain. He had worked as a waiter for over 10 years. He had quit smoking and drinking alcohol 6 months earlier, and denied any illicit drug use, sick contacts, animal exposure, or travel history.

On physical examination he was afebrile and hypoxemic. He had an unremarkable respiratory and cardiac examination. His laboratory values were notable for ele-

Drs Siddiqui and Badireddi are affiliated with the Division of Pulmonary and Critical Care; and Dr Saleem is affiliated with the Department of Internal Medicine, University of Arkansas for Medical Sciences, Little Rock, Arkansas.

The authors have no conflict of interests.

Correspondence: Mohammad F Siddiqui MD MPH, Division of Pulmonary and Critical Care Medicine, University of Arkansas for Medical Sciences, Little Rock AR 72211. E-mail: mfsiddiqui@uams.edu.

DOI: $10.4187 /$ respcare.02402 vated creatine kinase $(9,862 \mathrm{IU} / \mathrm{L}$, normal range $49-397 \mathrm{IU} /$ $\mathrm{L})$, creatine kinase $\mathrm{MB}(38 \mathrm{ng} / \mathrm{mL}$, normal range 0.2 $5.0 \mathrm{ng} / \mathrm{mL})$, troponin $(1.28 \mathrm{ng} / \mathrm{mL})$, aspartate aminotransferase (931 IU/L, normal range 15-41 IU/L), and alanine aminotransferase 2,315 IU/L (normal range 5$45 \mathrm{IU} / \mathrm{L}$ ). A urine drug screen for benzodiazepine, narcotics, cocaine, and methamphetamines was unremarkable. An electrocardiogram showed a normal sinus rhythm, with no evidence of new or old ischemic changes.

A chest radiograph showed only bibasilar atelectasis. Computed tomography revealed bilateral diffuse areas of ground glass opacities (Fig. 1). He was started on empirical antibiotic coverage for community-acquired pneumonia.

Flexible bronchoscopy revealed inflamed airways. Bronchoalveolar lavage cultures were unrevealing. Transbronchial biopsy of the right lower lobe showed multinucleated giant cell reaction with polarizable foreign material in a perivascular distribution (Fig. 2).

The presence of talc in the giant cell reaction prompted us to consider pulmonary talcosis secondary to intravenous drug abuse as the diagnosis. When confronted with the findings, the patient admitted to injecting himself with crushed oxycodone. He had associated rhabdomyolysis from the loss of consciousness, and prolonged immobility. He eventually was weaned off oxygen, and his laboratory abnormalities resolved. He was discharged to home but did not follow up with the pulmonary clinic, and we were unable to get any pulmonary function tests.

\section{Discussion}

Talc or magnesium silicate is a commonly used agent in industry and in daily life. Talc causes 2 broad categories of lung disease: one caused from talc inhalation, and the other from intravenous administration. Talco-silicosis and Talco-asbestosis result from occupational exposures to talc dust with high content of silica or asbestos fiber. Talcosis or talc pneumoconiosis was first reported in the nineteenth century, and is seen with industrial exposures in the mining, rubber, paint, ceramics, leather, and insecticide industries. Inhalation of pure talc, such as cosmetic talc, has also been reported to cause talcosis. ${ }^{1,2}$ Reports have described ARDS from inhalation of cosmetic talc. ${ }^{3}$ 


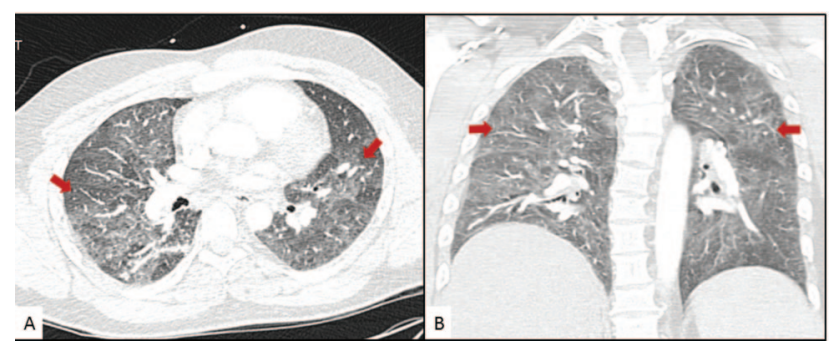

Fig. 1. A: Computed tomogram shows bilateral areas of micronodules and ground glass opacities. B: Coronal section shows areas of ground glass opacities in all lung fields.

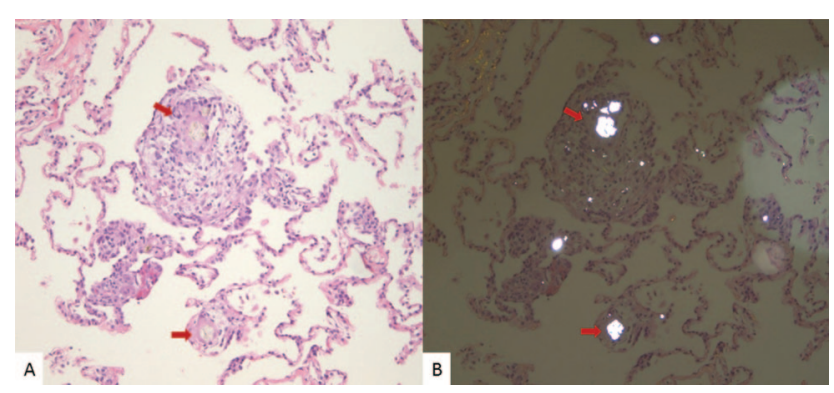

Fig. 2. A: Biopsy shows granulomatous reaction, giant cells, and foreign body (hematoxylin and eosin stain, magnification 10). B: Light microscopy shows polarizable material in the granulomatous reaction.

The common form of pulmonary talcosis is caused by intravenous administration of talc. Talc is a common bulking agent and lubricant in oral medications. In patients who use intravenous drugs, talcosis has been reported with a variety of agents, including methylphenidate, methadone, promethazine, cocaine, diazepam, acetaminophen, meperidine, pentazocine, oxymorphone, and heroin, among others. ${ }^{4-6}$ Talc is also commonly instilled in intrapleural spaces as a sclerosing agent for malignant pleural effusions. Lung manifestations from pleural instillation are not common, though cases of acute respiratory failure from systemic absorption of intrapleural talc have been reported..$^{7,8}$

Talc particles in crushed oral medications that are injected intravenously become entrapped in the pulmonary vasculature and can then move into the interstitium and cause a granulomatous reaction. These granulomas have giant cells that can be visualized as birefringent talc crystals with polarized light. ${ }^{9}$ The perivascular distribution of talc granulomas is a distinct finding of intravenous drug abuse, unlike inhaled talc, where the deposition is predominantly around respiratory bronchioles and alveolar ducts. Larger talc crystals are also suggestive of intravenous drug abuse. ${ }^{10}$ Talcosis has also been identified via scanning electron microscopy with energy-dispersive x-ray analysis, which identifies the ratio of magnesium and silicone in the granuloma crystals. ${ }^{11}$ Talc granulomas have also been described in other organs in intravenous drug abusers, but a characteristic finding is crystals in retinal vessels on fundoscopy.

Patients with talcosis can be asymptomatic or present with acute respiratory failure. Usually the symptoms are nonspecific and can include dyspnea, cough, fevers, night sweats, weight loss, and spontaneous pneumothorax. Pulmonary function tests usually show mixed obstructive and restrictive physiology, and a reduced diffusion capacity. As the disease progresses there is usually conglomeration of micronodules into masses, and emphysematous changes in the lung parenchyma. Later complications include chronic respiratory failure from emphysema, pulmonary hypertension from intravascular deposition of talc crystals, and right heart failure. ${ }^{12,13}$

The computed tomography manifestations of acute talcosis consist of a fine micronodular pattern (the nodules usually $\leq 1 \mathrm{~mm}$ ) and areas of ground-glass attenuation in all lung zones. Both centrilobular and panacinar emphysema patterns have been reported in intravenous drug users, with lower lobe panacinar pattern being the predominant finding. ${ }^{6}$ These emphysematous changes can resemble bullous sarcoidosis or alpha-1 antitrypsin deficiency. Progressive talcosis is seen as conglomerate masses in the upper lobes, with areas of high attenuation. ${ }^{14}$

Our patient had crushed an oral formulation of oxycodone and injected himself, which resulted in acute respiratory failure presenting with severe hypoxemia and manifesting on the computed tomogram as ground glass opacities and reticulonodular pattern. The talc granulomas were discovered on biopsy and established the diagnosis of respiratory failure from intravenous drug abuse

A good history, including detailed occupational or remote exposures, radiological correlation, and a lung biopsy, help establish the diagnosis of talcosis. Acute talcosis is generally treated with supportive measures, though use of steroids has been reported. Chronic talcosis can cause severe emphysema, and has been treated with lung transplant. ${ }^{15}$ Pulmonary hypertension from talcosis has been treated with vasodilator agents, with some success.

\section{Teaching Points}

- A good history, clinical suspicion, and biopsy help establish the diagnosis of talcosis from intravenous drug abuse.

- The presence of polarizable material in lung tissue is pathognomic of pulmonary talcosis.

- For acute pulmonary talcosis, management is with supportive care only. 


\section{Pulmonary Talcosis With Intravenous Drug Abuse}

\section{REFERENCES}

1. van Huisstede A, Noordhoek Hegt V, Otte-Holler I, LooijenSalamon M, Rudolphus A. Talcosis due to abundant use of cosmetic talcum powder. Eur Respir Rev 2010;19(116):165-168.

2. Pairaudeau PW, Wilson RG, Hall MA, Milne M. Inhalation of baby powder: an unappreciated hazard. BMJ 1991;302(6786):1200-1201.

3. Dekel Y, Rath-Wolfson L, Rudniki C, Koren R. Talc inhalation is a life-threatening condition. Pathol Oncol Res 2004;10(4):231-233.

4. Egan AJ, Tazelaar HD, Myers JL, Abell-Aleff PC. Munchausen syndrome presenting as pulmonary talcosis. Arch Pathol Lab Med 1999;123(8):736-738.

5. Sieniewicz DJ, Nidecker AC. Conglomerate pulmonary disease: a form of talcosis in intravenous methadone abusers. AJR Am J Roentgenol 1980;135(4):697-702.

6. Ward S, Heyneman LE, Reittner P, Kazerooni EA, Godwin JD, Müller NL. Talcosis associated with IV abuse of oral medications: CT findings. AJR Am J Roentgenol 2000;174(3):789-793.

7. Cardillo G, Facciolo F, Carbone L, Regal M, Corzani F, Ricci A, et al. Long-term follow-up of video-assisted talc pleurodesis in malignant recurrent pleural effusions. Eur J Cardiothorac Surg 2002; 21(2):302-305; discussion 305-306.

8. de Campos JR, Vargas FS, de Campos Werebe E, Cardoso P, Teixeira LR, Jatene FB, et al. Thoracoscopy talc poudrage: a 15-year experience. Chest 2001;119(3):801-806.
9. Marchiori E, Lourenco S, Gasparetto TD, Zanetti G, Mano CM, Nobre LF. Pulmonary talcosis: imaging findings. Lung 2010;188(2): 165-171.

10. Abraham JL, Brambilla C. Particle size for differentiation between inhalation and injection pulmonary talcosis. Environ Res 1980;21(1): 94-96.

11. Goldbach PD, Mohsenifar Z, Abraham JL, Young WI, Merrill WD. Talcum powder pneumoconiosis: diagnosis by transbronchial biopsy using energy-dispersive x-ray analysis. West J Med 1982;136(5): 439-442.

12. Roberts WC. Pulmonary talc granulomas, pulmonary fibrosis, and pulmonary hypertension resulting from intravenous injection of talccontaining drugs intended for oral use. Proc (Bayl Univ Med Cent) 2002;15(3):260-261

13. Griffith CC, Raval JS, Nichols L. Intravascular talcosis due to intravenous drug use is an underrecognized cause of pulmonary hypertension. Pulm Med 2012;2012:617531.

14. Marchiori E, Souza Junior AS, Muller NL. Inhalational pulmonary talcosis: high-resolution CT findings in 3 patients. J Thorac Imaging 2004;19(1):41-44.

15. Shlomi D, Shitrit D, Bendayan D, Sahar G, Shechtman Y, Kramer MR. Successful lung transplantation for talcosis secondary to intravenous abuse of oral drug. Int $\mathbf{J}$ Chron Obstruct Pulmon Dis 2008; $3(2): 327-330$ 